\title{
Is the Euphoria Surrounding Shariah-compliant Status Announcement long-lasting?- Event Study on Abnormal Returns of Incoming and Outgoing Firms in the Kuala Lumpur Shariah Index (KLSI) Listing
}

\author{
Rabuan Mantine ${ }^{1^{*}}$ and Mohamad Jais ${ }^{2}$ \\ ${ }^{1}$ School of Business and Management, University College of Technology Sarawak \\ ${ }^{2}$ Faculty of Economics and Business, Universiti Malaysia Sarawak \\ *Corresponding author: rabuanm1@gmail.com
}

\begin{abstract}
During the early years of Kuala Lumpur Islamic Index (KLSI), past literatures on the study of abnormal returns show investors' euphoria surrounding the launching of the index and subsequent later studies, the sustainability of the abnormal returns in the long-run by comparing the performances of the KLSI against the conventional counterpart, Kuala Lumpur Composite Index (KLCI). Abnormal returns of KLSI were found to be significant in the short-run but unfortunately, absent in the long-run. With more extensive panel data $(1999-2010)$, this study revisits the presence of the past euphoria by applying Buy-and-hold Abnormal Returns (BHAR) analysis. Unlike previous studies, this study assesses the short-run and long-run performances of the individual stocks rather than the index (KLSI) in order to remove the survivorship bias' drawback of previous studies. In addition, to complement previous studies, analysis on the performance of stocks 'expelled' from KLSI (after losing shariah-compliant certification) also conducted. The study reveals the favourable short-run and long-run impact on firms attaining shariah-compliant status and the unfavorable impacts on firms losing shariah-compliant status, indicating that the investors are optimistic on the performance of firms attaining shariah-compliant status and pessimistic on firms losing shariah-compliant status. In essence, the findings indicate that shariah-compliant status provides information on past and present performance of the firms.
\end{abstract}

Keywords: Abnormal Returns, Kuala Lumpur Shariah Index, Shariah-compliant,

\section{Introduction}

According to the efficient market hypothesis (EMH), it is impossible for the investors to achieve abnormally high returns, because the price of an asset includes all available information which may affect the price of the product (Altin, 2015). However, while EMH provides the basic logic for modern risk-based theories of asset prices, and frameworks, it fails to explain the phenomena or market anomalies which is in deviation of this model. This leads to later studies that suggest behavioural reason for such phenomena. In their seminal paper, Fama et al. (1969), propose the event study methodology and show that stock prices on average react before a stock split, but have no movement afterwards. Following Fama et al. (1969) other researchers apply event study to observe the immediate or short-run presence of abnormal returns in corporate events such as rights issues (Marsden, 2000), private placements (Anderson et al., 2006), demergers, cancellation of mergers and acquisitions (Pet et al., 2003), dividend payout (DeAngelo \& DeAngelo, 2006), bonus issues and splits (Ray, 2011), and even extended to non-corporate event such as election periods (Altin, 2015). 
With the emergence of Islamic investment phenomena in the late 1990's, similar event study also conducted specifically on Islamic investment such as Islamic Indices and Islamic Mutual Funds. Earlier researcher, Sadeghy (2008) reveals that the market has seen a positive reaction against the launch of the Kuala Lumpur Shariah Index (KLSI). Using bigger panel data, subsequent studies (Rahim \& Yong, 2010; Ahmad \& Ibrahim, 2002; Albaity \& Ahmad, 2008, 2011), however, failed to find the significant difference in the performance of KLSI and Kuala Lumpur Composite Index (KLCI) in the long-run.

One of the arguments among previous researchers are that the shariah-compliant firms have different profiles from conventional counterparts as the issuance of shariah-compliant status is stringent on prohibited elements such as usury (riba), gambling (maysir) and uncertainty (gharar) (Adam \& Bakar, 2014). Some suggest (Campbell \& Vuolteenaho, 2004; Geczy et al., 2005; Hong \& Kacperczyk, 2009) that the prohibition elements restrict the performance of shariah-compliant funds. While others on the contrary, (Hakim \& Rashidian, 2002; Hussein, 2005. Lee \& Faff, 2009) positively believe that shariah compliance encourages firms to adopt corporate responsibility policy to put them in a better position to avoid any environmental and social crises that could lead to reputation damage, higher production costs, lost production, higher security costs and increased insurance premium.

The limitation of past researches on shariah-compliant investment when comparing the performance of shariah-compliant firms, funds, screen or indices against their conventional counterparts is on the assumptions that the two types of investment are mutually exclusive. However, the fact that firms 'freely' enter or exit the shariah funds, screen or indices upon passing or failing shariah screening results in the past performances of some shariah-compliant firms newly attaining shariah-compliant status are measured in KLSI instead of the bigger universe of shariah non-compliant firms. Thus, the studies measure the performance of KLSI and its counterpart are comparing the homogeneousness of the data profiles of firms in the respectively indices instead of the impacts of shariah compliance to the firms.

This study contributes to the body of work that attempts to describe how current and past performance of firms are influenced by the shariah-compliant status changes i.e. either by attaining or losing the status. The relations between corporate events such as the launching of KLSI and IPOs of shariah-compliant firms and contemporaneous price changes reported in prior empirical studies (Sadeghy, 2008; Rahim \& Yong, 2010; Ahmad \& Ibrahim, 2002; Albaity \& Ahmad, 2008, 2011) suggest that shariah-compliant status provides relevant information to shareholders. However, it is not sufficient to pronounce the market is efficient with respect to this information to the extent that prices immediately and rapidly impound all the information relevant to valuing a firm.

The objective of this study is therefore to measure the impacts of changes in shariahcompliant status of firms in Bursa Malaysia in 2000 until 2009 by discriminating their shortrun and long-run abnormal returns based on the premise that attaining shariah-compliant status would have favourable, not only short-run but also long-run abnormal returns on firms as well. Thus, only firms with shariah-compliant status changes (attaining or losing shariah-compliant status) are considered. The performances of the same firms are compared prior and after attaining or losing shariah-compliant status (past and present performance). This study employs the buy-and-hold abnormal returns analysis (BHAR) methodology to observe longrun effect of the event from other general market movements. 


\section{Literature Review}

This study is built upon prior researches on the occurrences of the abnormal returns following major corporate events or decisions, where abnormal return is a term used to describe the returns generated by a given security or portfolio over a period of time that is different from the expected rate of returns. Abnormal returns are the crucial measure to assess the impact of an event. The general idea of this measure is to isolate the effect of the event from other general market movements. The measurement of abnormal returns are then performed to test various hypotheses on the impact of events on stocks, indices or screens.

Among the earlier studies on this regard, Loughran and Ritter (1995) analyzed the abnormal returns of firms on initial public offerings and seasoned equity offerings during the periods of 1970 to 1990 in the United States by correlating to the return benchmarks i.e., market index, size control firm and three-factor model developed by previous researchers, Fama and French (1993). The results show surprisingly low returns over holding periods of 2-5 years following the issue date. Focusing on clientele theory, Michaely et al. (1995) examined the turnover of both dividend initiating and dividend omitting firms in NYSE/AMEX during the years 1964 until 1988. They concluded that the relatively minor increase in volume around the event and the absence of an increase in the six months thereafter was too low to be consistent with a significant clientele shift.

Decades later, with the birth of Kuala Lumpur Shariah Index (KLSI) similar event studies were carried out by Sadeghi (2008) and also subsequently by Rahim and Yong (2010). Sadeghi examines the impact of the introduction of shariah-compliant index by Bursa Malaysia on the performance and liquidity of the included shares in days surrounding the event while Rahim and Yong focus on the difference in IPOs performance of shariah-compliant firms against its shariah non-compliant counterparts. Findings by Sadeghi show that, the introduction of shariah-compliant index has positive impact on the overall financial performance of the included shares. However, the study focuses only on firms available during the launching date of shariah-compliant index in 1999. Rahim and Yong (2010) on the other hand, use more comprehensive data with samples of 386 IPOs issued between January 1999 and December 2007. They examine the effect of shariah-compliant status on the performance of Malaysian IPOs and whether shariah-compliant status would alter such patterns. Their results suggest that subsample of firms with shariah-compliant status show similar profiles to those of shariah non-compliant counterparts. However, they find the two subsamples are driven by different factors. Initial returns of shariah-compliant IPOs are driven by the size and type of offers, whereas those of the shariah non-compliant IPOs are driven by risks.

Using non-event methods Ahmad and Ibrahim (2002) and also Albaity and Ahmad (2008) examine the performance of KLSI in Bursa Malaysia against its conventional counterpart Kuala Lumpur Composite index (KLCI). Albaity and Ahmad (20011) again reexamine the performance of shariah-compliant firms against their conventional part, shariah non-compliant firms in Bursa Malaysia. The study by Ahmad and Ibrahim (2002) investigates the risk and return performance comparison of both KLSI with KLCI from 1999 to 2002 in Malaysia. The sample period of the study is divided into growing period, decline period and overall period. Relative return technique, standard deviation, and risk adjusted return are used to measure the performance of both indices. The study finds that KLSI underperformed during overall period and the decline period but it over-performed in the growing period. Their study also finds no significant difference in the performance of both indices during the three sample periods. By using longer observation periods from 1999 to 2005, Albaity and Ahmad (2008) 
examine the performance and relationship of the KLSI against the KLCI. The study employs risk adjusted performance measurement, causality and Johansen co-integration test. The statistical results on their risk and returns, measured by the mean and standard deviation, suggest that KLSI has lower risk exposure than KLCI although it also has a lower return. However, their study finds that there was no significant return difference and long-run bidirectional relationship between both indices. Albaity and Ahmad (2011) further investigated the return difference between shariah-compliant and shariah non-compliant firms listed on the Malaysian Stock Exchange using panel data of 300 firms from the period of 2000 to 2006. The determinants of stock returns used are market capitalization, market-to-book ratio, Price Earnings ratio, market risk and total debt. The study finds that there are no significant difference between shariah-compliant firms and their counterparts. For shariah-compliant firms, it was found that the size and market-to-book ratios are the most significant variables explaining returns. However, for shariah non-compliant firms, market-to book-ratio and market risk are the most significant variables that influenced return.

The event study carried out by Sadeghi (2008) on KLSI however, only explains the euphoria surrounding the inception of the new shariah index that was launched in 1999 and thus not measuring the long-run performance of the shariah-compliant firms. Similar study performed by Rahim and Yong (2010) on IPOs of shariah-compliant firms covers longer observation periods ( 8 years) but still the measurement is on the initial returns surrounding the event. Thus, their studies only measure the temporary price volatility of firms on the launching day which could have been driven by hype or "buzz" caused by press coverage, rumor, speculation and even a well-publicized IPOs rather than the underlying fundamentals of the firms.

Studies by Ahmad and Ibrahim (2002) and also Albaity and Ahmad (2008) compare the long-run performance of KLSI and KLCI using panel data from 1999 to 2002 (4-year period) and 1999 to 2005 (7-year period) respectively. It should be highlighted here that during the periods under study many movements of firms in KLSI must have occurred. In fact, based on the circulars issued by the Securities Commission of Malaysia between 2000 and 2009, about 693 new firms added in and 186 firms exited the KLSI (movement of same firm more than once counted as one only). Firms exited KLSI would form the bigger universe of shariah non-compliant firms, while the 'selected' firms remained in KLSI. As a result, there is a tendency of 'survivorship bias' occurrence as shariah-compliant firms with poor performance to be dropped by KLSI, generally because of poor results or low asset accumulation. This phenomenon, originally observed in the fund industry by Elton et al. (1996), results in an overestimation of the past returns of mutual funds where poor performing funds were dropped from their scheme to reflect higher average returns.

\section{Data and Methodology}

\section{The Sample of Firms with Shariah-compliant Status Changes}

The sample is drawn from all firms on the Bursa Malaysia which are added in or deleted from Kuala Lumpur Shariah Index (KLSI) (for passing or failing the shariah-compliant screening process) through the announcements made by Securities Commission of Malaysia which are issued through its' Circulars between 2000 and 2009. However, the samples collected are from 1999 to 2010 period to fulfil the minimum requirement that at least one year of data are available before and after the shariah-compliant addition or deletion announcement. To be included in the sample, a firm must satisfy the following criteria: 
Borneo Journal of Social Sciences \& Humanities

DOI: https://doi.org/10.35370/bjssh.2021.3.1-07

e-ISSN: 2682-8235

(C) 2018, UCTS Publisher.

Submitted: 18 March 2021

Accepted: 12 May 2021

Published: 30 June 2021

i. The firm's financial data are available on Data Stream;

ii. The firms with no shariah-status changes are excluded (thus firms which have been added or deleted from shariah index prior to the year 2000 and maintained the same status throughout the period under study are disqualified);

iii. A firm should not be added and deleted from shariah-compliant listing more than once. (This condition further eliminates firms with inconsistent shariah-compliant status);

iv. Available data for minimum period prior (-1) one year and post (+1) also one year. (This condition eliminates firms added to the shariah-compliant index during the Initial Public Offerings (IPOs) as well as those firms that remain in the shariah-compliant listing during the period under study); and

v. Firms already delisted from Bursa Malaysia during the period under study (1999-2010) are excluded.

The numbers of firms attaining shariah-compliant status for the period of 2000-2009 are 693 firms excluding those listed during the launching of Kuala Lumpur Shariah Index (KLSI) in 1999 whereas those losing shariah-compliant status are 186. However, the number selected for the samples slightly reduced after closer inspection and selection based on the study criteria set above. The Firms attaining and losing shariah-compliant status are illustrated in Figure 1.

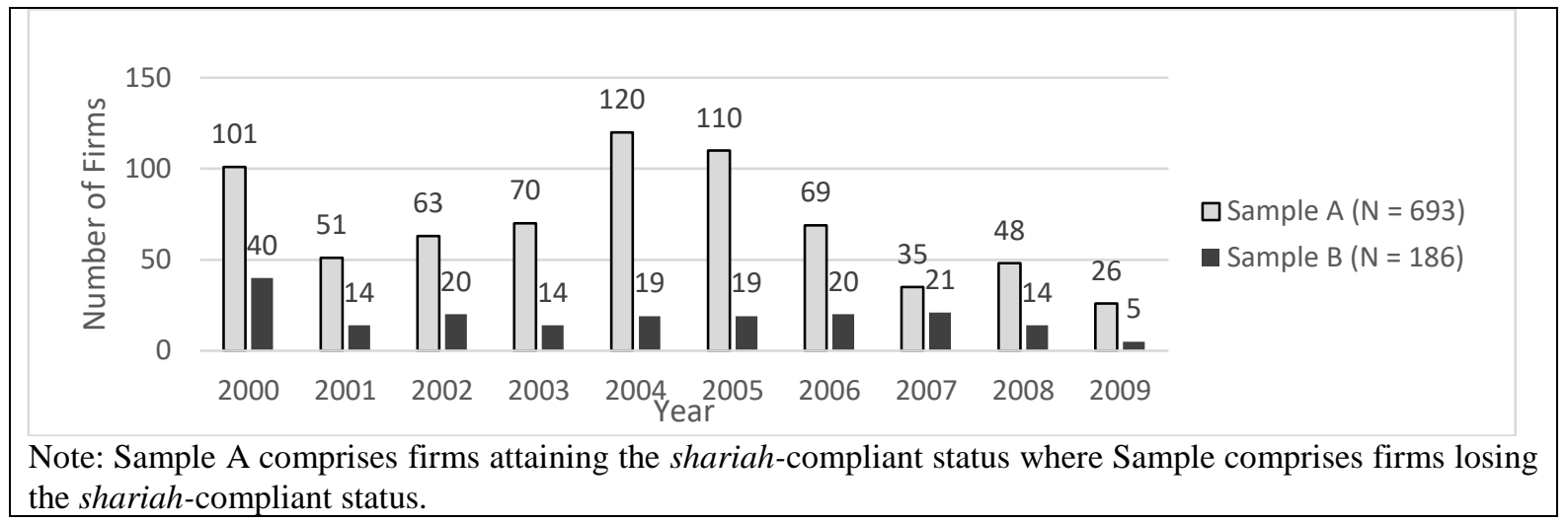

Figure 1: Firms Attaining and Losing Shariah-Compliant Status As Announced By Securities Commission of Malaysia for the Periods 2000-2009

Source: Securities Commission of Malaysia 


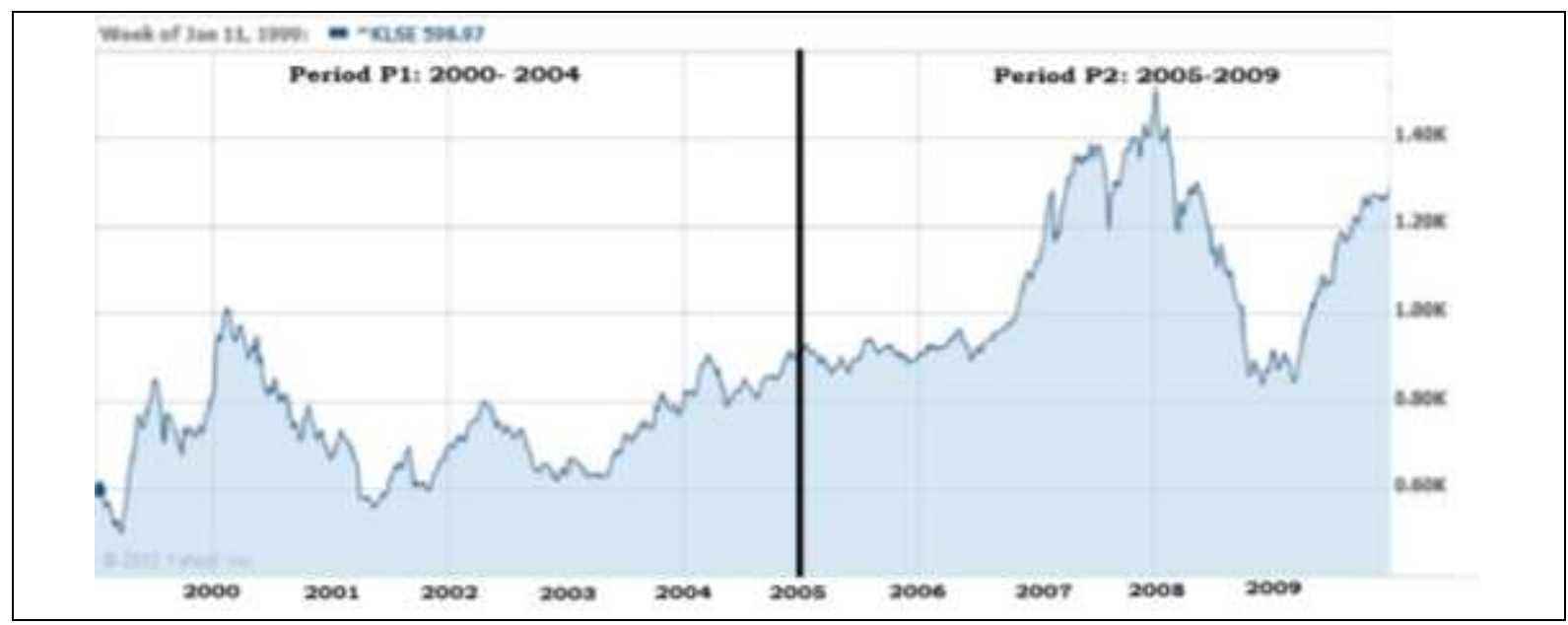

Figure 2: KLCI Market Performance in 2000 - 2009

Source: Yahoo finance website (finance.yahoo.com)

\section{The Effect of Different Market Conditions}

In order to capture the effects of different market conditions, the event period under study are further divided into market recovery period (Period-P1: 2000-2004) and market stability period (Period-P2: 2005-2). The graphic presentation of the market performance of Bursa Malaysia during the periods is shown in figure 2.

\section{Buy-and-hold Abnormal Returns (BHAR) analysis}

Event study is an empirical study performed on a security that has experienced a significant catalyst occurrence, and has subsequently changed dramatically in value as a result of that catalyst. The event can have either a positive or negative effect on the value of the security.

Buy-and-hold, on the other hand, is an investment strategy in which one does not do any trading on a portfolio between the initial selection of the securities and the end of a certain time period (which is usually a long time). A buy-and-hold strategy ignores short and mediumterm trends and concentrates exclusively on the long-term.

In this analysis, standard event study methodology as elaborated by Campbell et al. (1997) is used to examine the market reaction to the shariah-compliant/non-compliant status change announcement analysing both short-run and long-run abnormal returns.

The standard short-run event study methodology assumes efficient capital markets wherein all of the information available about a firm is quickly incorporated into the price of the firm's stock. Hence, the traditional short-run event study measures the abnormal change in a stock price over a very short window, typically one day before to one day after the event (Subramani \& Walden, 2002). However, in the initial phases of a new commerce paradigm markets may not have access to high-quality information about the new standard because the information has not yet been generated. In such a situation, the short-run evaluations might be misleading. However, in the long-run as investors gain more information about how a firm pursues an initiative, how customers react to the initiative, how competitors respond to the initiative and how overall perceptions of investors change they may very well revise their initial opinions (Abarbanell, 1991; Abarbanell \& Bernard, 1992). Given the new information gained over the long-run investors may rebalance their portfolios thereby changing the level of abnormal returns. Therefore a long-run event study may offer greater insight into the domain of question and add or perhaps subtract validity to other short-run event studies in the literature. 
Borneo Journal of Social Sciences \& Humanities

DOI: https://doi.org/10.35370/bjssh.2021.3.1-07

e-ISSN: 2682-8235

(C) 2018, UCTS Publisher.

Submitted: 18 March 2021

Accepted: 12 May 2021

Published: 30 June 2021

The objective of the study, as mentioned in earlier paragraph, which is to measure the impacts of changes in shariah-compliant status of firms in Bursa Malaysia by discriminating their short-run and long-run abnormal returns is further developed into the hypotheses as below:

H1: Firms attaining shariah-compliant status would have favourable short-run and long-run abnormal returns

H2: Firms losing shariah-compliant status would have unfavourable short-run and long-run abnormal returns.

The short-run returns surrounding the event day as well as the long-run after-event returns are examined by computing buy-and-hold abnormal returns (BHRs). The calculations for both short-run and long-run returns are basically the same except for the time windows applied. The stocks return windows (event period) begins one (1) day prior and ends ten (10) days post-announcement of the shariah-compliant status for the buy-and-hold short-run returns whereas buy-and-hold long-run returns starts from three to twelfth-month periods after event. Time-lines for both event short-run and long-run event studies are illustrated in Figure 3 and Figure 4 as follows:

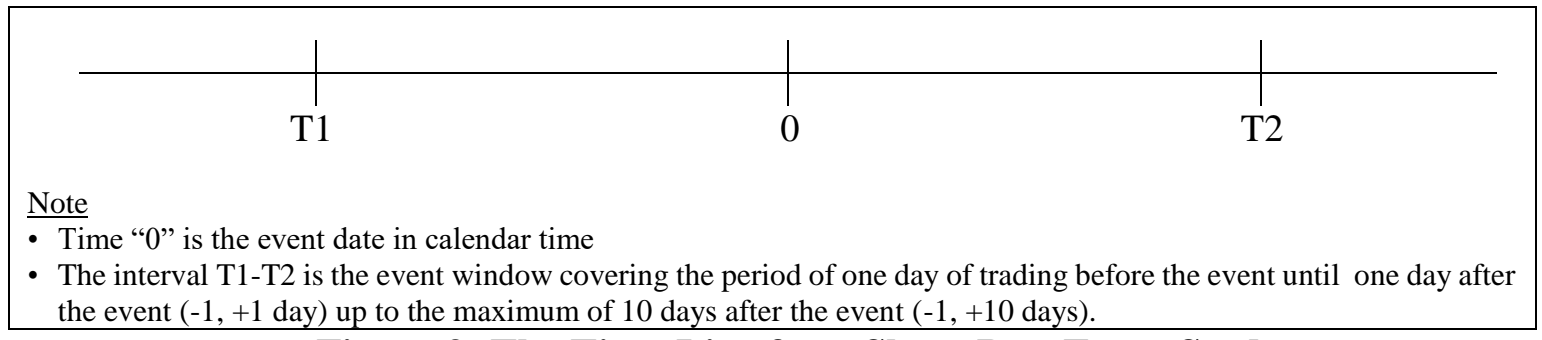

Figure 3: The Time-Line for a Short-Run Event Study

Source: Authors

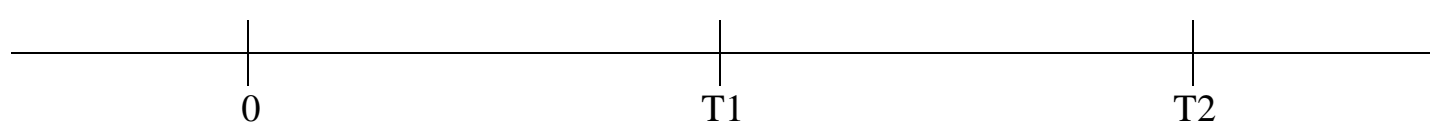

Note

- Time " 0 " is the event date in calendar time

- The interval T1-T2 is the event window covering the period starting from the end of the event month until the end of third month after the event $(0,+3$ months) up to the maximum of the twelfth months after the event $(0,+12$ months).

\section{Figure 4: The Time-Line for a Long-Run Event Study}

Source: Authors

According to Barber and Lyon (1997) the researchers should calculate abnormal returns as simple buy-and-hold returns on a sample firms less the buy-and-hold returns on a benchmark portfolio or control firms. The BHRs on company $i$ are defined as;

$$
\begin{aligned}
& B H R_{i, D}=\left[\prod_{d=-1}^{D}\left(1+r_{i, D}\right)\right]-1, D=[1,2,3,4,5,10] \text { for short-run returns, or; } \\
& B H R_{i, T}=\left[\prod_{t=0}^{T}\left(1+r_{i, T}\right)\right]-1, T=[3,5,6,9,12] \text { for long-run returns }
\end{aligned}
$$


Where;

$R_{i, D}=$ short-run returns of company $i$ in period $d ;$

$R_{i, T}=$ long-run returns of company $i$ in period $t$;

$d=-1$ indicates the trading day one (1) day before the event;

$t=0$ indicates trading day at the end of the month after the event;

$D=$ trading day up to $10^{\text {th }}$ days post event;

$T=$ anniversary month up to $12^{\text {th }}$ anniversary month post event trading day.

Therefore, buy-and-hold abnormal returns (BHAR) over identical intervals are calculated for each company by and their corresponding benchmarks are as follows ${ }^{1}$;

$B H A R_{i, D}=B H R_{i, D}-B H R_{B, i, D}$, for the short-run, or;

$B H A R_{i, T}=B H R_{i, T}-B H R_{B, i, T}$, for the long-run

Then the average buy-and-hold total abnormal returns are derived by averaging equation (2) over the events results of sample $n$ firms as below;

$$
\begin{array}{ll}
\overline{B H A R}_{D}=\frac{1}{n} \sum_{i=1}^{n}\left[B H A R_{i, D}\right], & \text { for the short-run, or; } \\
\overline{B H A R}_{T}=\frac{1}{n} \sum_{i=1}^{n}\left[B H A R_{i, T}\right], & \text { for the long-run }
\end{array}
$$

To test the null hypothesis of zero mean buy-and-hold abnormal returns, the bootstrapped skewness-adjusted $t$-statistic proposed by Lyon et al. (1999) was used. The $t$-statistic is formulated as follows;

$$
t_{B H A R}=\sqrt{\mathrm{n}}\left(S+\frac{1}{3} \hat{y} S^{2}+\frac{1}{6} n \hat{y} S^{2}\right)
$$

Where;

$$
\begin{aligned}
S & =\frac{\overline{B H A R}_{D}}{\sigma\left(B H A R_{i, D}\right)}, \text { for short-run; or } \\
S & =\frac{\overline{B H A R}_{T}}{\sigma\left(B H A R_{i, T}\right)}, \text { for long-run; and } \\
\hat{y} & =\frac{\sum_{i=1}^{n}\left(B H A R_{i, D}-\overline{B H A R}_{D}\right)^{3}}{n \sigma\left(B H A R_{i, D}\right)^{3}} \text { for short-run; or } \\
\hat{y} & =\frac{\sum_{i=1}^{n}\left(B H A R_{i, T}-\overline{B H A R}_{T}\right)^{3}}{n \sigma\left(B H A R_{i, T}\right)^{3}} \text { for long-run. }
\end{aligned}
$$

Note that $\hat{y}$ is an estimate of the coefficient of skewness and $\sqrt{\mathrm{n}}(S)$ is the conventional $t$-test equation.

\footnotetext{
${ }^{1}$ The obvious difference between CARs and BHARs models is, among others, the effect of monthly compounding, CARs ignores compounding, while BHARs include the effect of compounding. The preference of Model BHARs over CARs for long run analysis in the event study methodology is deliberated by Barber and Lyon (1997).
} 
Borneo Journal of Social Sciences \& Humanities

DOI: https://doi.org/10.35370/bjssh.2021.3.1-07

e-ISSN: 2682-8235

(C) 2018, UCTS Publisher.

Submitted: 18 March 2021

Accepted: 12 May 2021

Published: 30 June 2021

\section{Results}

The summary of the results obtained with respect to short-run buy-and-hold abnormal returns (BHARs) and long-run buy-and-hold abnormal returns $\left(\right.$ BHAR $\left._{\mathrm{L}}\right)$ are presented in Table 1 and Table 2 whereas the details are presented in Table 3 and Table 4 respectively. The results confirmed the notions in Hypothesis \#1 that firms attaining shariah-compliant Status (Sample A) have favourable short-run and long-run abnormal returns and also in Hypothesis \#2 where firms losing shariah-compliant status (Sample B) have unfavourable short-run and long-run abnormal returns.

Table 1 Summary of BHAR Event Study's Results for Sample A

\begin{tabular}{|c|c|c|}
\hline & Short-run BHAR (or BHARs) & 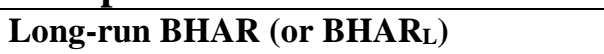 \\
\hline $\begin{array}{l}\text { Overall period } \\
(2000-2009)\end{array}$ & $\begin{array}{l}\text { Positive (+ve) abnormal returns within } 5 \\
\text { days of event windows }(-1,+5)\end{array}$ & $\begin{array}{l}\text { Positive }(+v e) \text { abnormal returns in the } \\
\text { three-month event windows }(0,+3)\end{array}$ \\
\hline $\begin{array}{l}\text { Recovery Period } \\
(2000-2004)\end{array}$ & $\begin{array}{l}\text { Positive (+ve) abnormal returns within } 5 \\
\text { days of event windows }(-1,+5)\end{array}$ & $\begin{array}{l}\text { No abnormal returns detected in all long- } \\
\text { run event windows }\end{array}$ \\
\hline $\begin{array}{l}\text { Stability Period } \\
(2005-2009)\end{array}$ & $\begin{array}{l}\text { Positive (+ve) abnormal returns within } \\
\text { one-day of event windows }(-1,+1)\end{array}$ & $\begin{array}{l}\text { Positive (+ve) abnormal returns in the } \\
\text { three-month event windows }(0,+3)\end{array}$ \\
\hline
\end{tabular}

Note: The positive abnormal returns indicate that investors react positively to the inclusion of the firms to the Kuala Lumpur Shariah Index (KLSI)

Source: Authors

Table 2 Summary of BHAR Event Study's Results for Sample B

\begin{tabular}{lll}
\hline & Short-run BHAR (or BHARs) & Long-run BHAR (or BHARL) \\
\hline $\begin{array}{l}\text { Overall period } \\
\mathbf{( 2 0 0 0 - 2 0 0 9 )}\end{array}$ & $\begin{array}{l}\text { Negative (-ve) abnormal returns within } \\
\text { one-day of event windows }(-1,+3) .\end{array}$ & No abnormal returns detected. \\
$\begin{array}{l}\text { Recovery Period } \\
\mathbf{( 2 0 0 0 - 2 0 0 4 )}\end{array}$ & $\begin{array}{l}\text { Negative (-ve) abnormal returns within } \\
\text { three-day of event windows }(-1,+4)\end{array}$ & No abnormal returns detected. \\
$\begin{array}{l}\text { Stabilized Period } \\
\mathbf{( 2 0 0 5 - 2 0 0 9 )}\end{array}$ & No abnormal returns were detected & $\begin{array}{l}\text { Negative (-ve) abnormal returns in nine } \\
\text { month event windows }(0,+9)\end{array}$ \\
\hline
\end{tabular}

Note: The negative abnormal returns indicate that investors react negatively to the exclusion of the firms from the Kuala Lumpur Shariah Index (KLSI)

Source: Authors

Table 3 Details of Short-run $B H A R_{S}$ Event Study's Results on Sample A and Sample B

\begin{tabular}{|c|c|c|c|c|c|c|}
\hline \multirow{3}{*}{$\begin{array}{l}\text { Event } \\
\text { Window } \\
\text { (Day) }\end{array}$} & \multicolumn{2}{|c|}{$\begin{array}{c}(2000-2009) \\
(\text { Overall Period })\end{array}$} & \multicolumn{2}{|c|}{$\begin{array}{c}\text { Period-P1 (2000-2004) } \\
\text { (Recovery Period) }\end{array}$} & \multicolumn{2}{|c|}{$\begin{array}{c}\text { Period-P2 (2005-2009) } \\
\text { (Stability Period) }\end{array}$} \\
\hline & $\begin{array}{l}\text { Mean } \\
\text { BHAR }\end{array}$ & t-statistics & Mean BHARS & t-statistics & Mean BHARs & t-statistics \\
\hline & \multicolumn{6}{|c|}{ (Sample A) } \\
\hline$(-1,+1)$ & $0.0108^{* * * *}$ & 4.2603 & $0.0093^{* * *}$ & 3.1548 & $0.0126^{* * * *}$ & 2.7620 \\
\hline$(-1,+2)$ & $0.0091^{* * * *}$ & 2.9161 & $0.0126^{* * *}$ & 3.4412 & 0.0048 & 0.9300 \\
\hline$(-1,+3)$ & $0.0074^{*}$ & 1.7586 & $0.0085^{*}$ & 1.9204 & 0.0061 & 0.7951 \\
\hline$(-1,+4)$ & $0.0099^{* *}$ & 2.3474 & $0.0099^{* *}$ & 2.3048 & 0.0099 & 1.2298 \\
\hline$(-1,+5)$ & $0.0102^{* *}$ & 2.2674 & $0.0136^{* * *}$ & 2.8388 & 0.0061 & 0.7428 \\
\hline$(-1,+10)$ & 0.0039 & 0.6757 & 0.0048 & 0.8025 & 0.0029 & 0.2977 \\
\hline$d f$ & & 290 & & 159 & & 130 \\
\hline
\end{tabular}


Borneo Journal of Social Sciences \& Humanities DOI: https://doi.org/10.35370/bjssh.2021.3.1-07 e-ISSN: 2682-8235

(C) 2018, UCTS Publisher.

Submitted: 18 March 2021

Accepted: 12 May 2021

Published: 30 June 2021

\begin{tabular}{|c|c|c|c|c|c|c|}
\hline \multirow[b]{2}{*}{$(-1,+1)$} & \multicolumn{6}{|c|}{ (Sample B) } \\
\hline & -0.0095 & -1.6915 & $-0.0237^{* *}$ & -2.2729 & -0.0011 & -0.1587 \\
\hline$(-1,+2)$ & $-0.0106^{*}$ & -2.0865 & $-0.0171^{*}$ & -1.9069 & -0.0067 & -1.1039 \\
\hline$(-1,+3)$ & $-0.0114^{*}$ & -1.7331 & $-0.0308^{* * *}$ & -6.6451 & 0.0000 & 0.0658 \\
\hline$(-1,+4)$ & -0.0058 & -0.5818 & $-0.0408^{* * *}$ & -8.0862 & 0.0147 & 1.5110 \\
\hline$(-1,+5)$ & -0.0015 & -0.1058 & -0.0175 & -1.0995 & 0.0079 & 0.6061 \\
\hline$(-1,+10)$ & -0.0122 & -1.1422 & -0.0132 & -1.0134 & -0.0117 & -0.7535 \\
\hline$d f$ & & 26 & & 9 & & 16 \\
\hline
\end{tabular}

Note: Sample A comprises firms attaining shariah-compliant status and included in the Islamic index and the event is the announcement date of their inclusion. On the other hand, Sample B consists of firms losing shariahcompliant status and excluded from the Islamic index and the event is therefore the announcement date of their exclusion. $* * *, * * *$ denote significant levels (two-tailed) at $1 \%, 5 \%$ and $10 \%$ respectively

Source: Authors

The study is also extended to the analysis on the long-run abnormal returns, in order to observe the long-term difference in market performance between firms attaining shariahcompliant status (Sample A) and firms losing shariah-compliant status (Sample B). which As shown in Table 4, interestingly, the results upheld the hypothesis that firms attaining shariahcompliant status have favourable short-run and long-run abnormal returns whereas firms losing shariah-compliant status have unfavourable short-run and long-run abnormal returns. While firms in Sample A registered significant positive abnormal returns in $(0,+3)$ month event window at $10 \%$ and 5\% levels during overall and market stability period (Period-P2) respectively, firms in Sample B, on the contrary, did not register any significant abnormal returns for the entire event windows except during market stability period (Period-P2) except during $(0,+9)$ month event window which has registered negative means $B H A R_{L}$ at -0.0965 significant at $5 \%$ level. Thus, the results indicate the presence of occasional market excitement in the long-run for firms attaining shariah-compliant status especially during market stability period. While, on the other hand, the results also point to fact that the market, especially during stability period, was still jittery on the long term performance and values of firms losing shariah-compliant status.

Table 4 Details of Long-run $B H A R_{L}$ Event Study's Results on Sample A and Sample B

\begin{tabular}{|c|c|c|c|c|c|c|}
\hline \multirow{3}{*}{$\begin{array}{c}\text { Event } \\
\text { Window } \\
\text { (Month) }\end{array}$} & \multicolumn{2}{|c|}{$\begin{array}{c}(2000-2009) \\
(\text { Overall Period })\end{array}$} & \multicolumn{2}{|c|}{$\begin{array}{c}\text { Period-P1 (2000-2004) } \\
\text { (Recovery Period) }\end{array}$} & \multicolumn{2}{|c|}{$\begin{array}{c}\text { Period-P2 }(2005-2009) \\
\text { (Stability Period })\end{array}$} \\
\hline & Mean $B H A R_{L}$ & $t$-statistics & Mean $B H A R_{L}$ & t-statistics & Mean BHAR $R_{L}$ & t-statistics \\
\hline & \multicolumn{6}{|c|}{ (Sample A) } \\
\hline$(0,+3)$ & $0.0227^{*}$ & 1.7081 & 0.0089 & 0.5183 & $0.0396^{* *}$ & 2.0123 \\
\hline$(0,+5)$ & -0.0385 & -1.5100 & -0.0904 & -1.2931 & 0.0238 & 0.8477 \\
\hline$(0,+6)$ & -0.0155 & -0.5224 & -0.0693 & -1.1004 & 0.0498 & 1.5335 \\
\hline$(0,+9)$ & -0.0007 & 0.0225 & -0.0615 & -1.1364 & 0.0723 & 1.4937 \\
\hline$(0,+12)$ & 0.0028 & 0.0958 & -0.0728 & -1.2210 & 0.0935 & 1.5992 \\
\hline \multirow[t]{2}{*}{$d f$} & & 294 & & 160 & & 133 \\
\hline & \multicolumn{6}{|c|}{ (Sample B) } \\
\hline$(0,+3)$ & -0.0264 & -1.2438 & 0.0055 & 0.1785 & -0.0442 & -1.9953 \\
\hline$(0,+5)$ & -0.0240 & -0.4153 & 0.0241 & 0.2560 & -0.0508 & -1.4478 \\
\hline$(0,+6)$ & -0.0221 & -0.4381 & 0.0504 & 0.5481 & -0.0624 & -1.3626 \\
\hline$(0,+9)$ & -0.0725 & -1.2522 & -0.0294 & -0.1781 & $-0.0965^{* *}$ & -2.1480 \\
\hline$(0,+12)$ & -0.0526 & -0.6881 & -0.0533 & -0.2507 & -0.0522 & -1.0439 \\
\hline
\end{tabular}


Borneo Journal of Social Sciences \& Humanities

DOI: https://doi.org/10.35370/bjssh.2021.3.1-07

e-ISSN: 2682-8235

(C) 2018, UCTS Publisher.

Submitted: 18 March 2021

Accepted: 12 May 2021

Published: 30 June 2021

$\begin{array}{llll}d f & 27 & 9 & 17\end{array}$

Note: Sample A comprises firms attaining shariah-compliant status and included in the Islamic index and the event is the announcement date of their inclusion. On the other hand, Sample B consists of firms losing shariahcompliant status and excluded from the Islamic index and the event is therefore the announcement date of their exclusion. $* * *, * *, *$ denote significant levels (two-tailed) at $1 \%, 5 \%$ and $10 \%$ respectively

Source: Authors

\section{Discussions}

The results on the market reaction to the firms attaining shariah-compliant status above are inconsistent with the findings by Sadeghi (2008) where he, contrary to these findings, finds the negative short-term market reaction to the launching of shariah Index in 1999. He, however, similar to these findings, finds the market reacted positively to the introduction of shariah index over longer period. Nevertheless, as stated in his paper, his study is confined to the launching date of the shariah index as the event while this study focuses on the subsequent inclusion of firms into the shariah index. Thus, the market condition in his study is therefore limited to the launching date in 1999 only while this study covers both market recovery period (2000-2004) and market stability period (2005-2009). The results above are also different from the findings of the study by Rahim and Yong (2010), which find shariah-compliant firms' IPOs as having similar profiles to those of non-shariah counterparts. Obviously, the difference stems from the focus of this study, unlike Rahim and Yong (2010), the IPOs are excluded in this study in order to emphasize on the effect of firms attaining shariah-compliant status while already listed in the stock market rather than measuring the superficial euphoria surrounding IPOs.

The results of the long run performance of the shariah-compliant firms also found to be different from the results of the studies by Ahmad and Ibrahim (2002) and also Albaity and Ahmad (2008 \& 2011). Unlike the findings by Ahmad and Ibrahim (2002), this study finds firms obtaining shariah-compliant status still showed positive long term abnormal returns, up to three month event window, especially during the stability period, in contrast with firms losing shariah-compliant status which showed negative abnormal returns up to nine month event window. Ahmad and Ibrahim (2002), on the other hand, find KLSI underperformed its counterpart, KLCI in all observations with the exception of growing period where observations are divided into growing, declining and overall periods. Albaity and Ahmad (2008, 2011), also ironically, find that there was no significant return difference and long-run bidirectional relationship between KLSI and KLCI in their earlier study and between shariah-compliant and non shariah-compliant firms in their subsequent study. Although, the contrasting results could be attributed to the difference in methods being used and also the objectives of the previous two studies as compared to this study, it should be emphasised here that conclusive inference could not be drawn on the effect of shariah compliance on firms, simply by comparing the performance of KLSI and KLCI or other shariah non-compliant counterparts, because the anomalies as a result of the survivorship bias as raised by Elton et al. (1996) are still not appropriately addressed. Thus, comparing KLSI and KLCI or other shariah non-compliant counterparts only measures the effectiveness of the "streaming process" funnelling firms from or to KLSI by the Securities Commissions of Malaysia rather than the effects of shariah compliance on firms. 


\section{Conclusions}

Taking cue from the drawbacks of previous studies, this study focuses on the impacts of firms' compliance to shariah rules by analysing the performance of firms experiencing changes in their shariah compliance status, either the attainment of the status to shariah-compliant firms or the annulment of the status to become shariah non-compliant firms.

The findings reveal that, the attainment of shariah-compliant status positively improved the performance of the firms and the opposite is true for the effect of the annulment of shariah-compliant status from the firms. Specifically, in the event study employed using BHAR analysis, the results showed that the market is favourable to firms accorded shariahcompliant status and pessimistic to firms losing shariah-compliant status implying that ethical principals in shariah-compliant firms have broad-based appeal to non-Muslim market as well. The results are in line with premise that postulates firms attaining shariah-compliant status as having favourable long-run and short-run abnormal returns.

\section{Recommendations/ Policy Implications}

The principal findings of this study indicate that Islamic investors may not necessarily have to pay an opportunity cost for adhering to their faith in Islamic investing. To be sure, the inclusions of firms in the Islamic index have attracted favourable response by the market which comprises non-Muslim investors as well which come to show the universality of the Islamic values in finance as demonstrated by the results of BHAR test.

Thus, shariah compliance screening processes are also beneficial for corporate managers, Muslim and non-Muslim alike, as they provide the right financial disciplines to be used as a guide to steer firms to the greater height.

\section{References}

Abarbanell. \& Jeffery S. (1991). Do analysts' earnings forecasts incorporate information in prior stock price changes? Journal of Accounting and Economics, 14(2), 147-165.

Abarbanell, J.S. \& Bernard. V.L (1992). Tests of analysts' overreaction/ underreaction to earnings information as an explanation for anomalous stock price behaviour. Journal of Finance 47, 1181-1207.

Adam, N. L. \& Abu Bakar, N. (2014). Shariah Screening Process in Malaysia, Procedia Social and Behavioral Sciences, 121, 113 - 123

Ahmad, Z. \& Ibrahim, H. (2002). A study of the performance of the KLSE Syari'ah index. Malaysian Management Journal, 6 (1), 25-34.

Albaity, M. \& Ahmad, R. (2008). Performance of shariah and Composite Indices: Evidence from Bursa Malaysia. Asian Academy of Management Journals of Accounting and Finance, vol. 4, no. 1, pp. 23-43.

Albaity, M. \& Ahmad, R. (2011). A Comparative Analysis of the Firm Specific Determinants of shariah Compliant Versus on-shariah Compliant Firms in Bursa Malaysia. Asian Journal of Business and Accounting, 4(1), pp. 59-84.

Altin, H. (2015). Efficient Market Hypothesis, Abnormal Return and Election Periods. European Scientific Journal, 11 (34). 
Borneo Journal of Social Sciences \& Humanities

DOI: https://doi.org/10.35370/bjssh.2021.3.1-07

e-ISSN: 2682-8235

(C) 2018, UCTS Publisher.

Submitted: 18 March 2021

Accepted: 12 May 2021

Published: 30 June 2021

Anderson, H., Rose, L., \& Cahan, S. (2006). Differential Shareholder Wealth and Volume Effects Surrounding Private Equity Placements in New Zealand. Pacific-Basin Finance Journal, 14, 367- 394.

Barber, B. M. \& Lyon, R. (1997). Detecting long-run abnormal stock returns: The empirical power and specification of test statistics. Journal of Financial Economics, 43, 341-372.

Campbell, J. Y. \& Vuolteenaho, T. (2004), Bad beta, good beta. American Economic Review, 94(5), 1249-1275.

Campbell, J., Lo, A., \& MacKinley, A.C. (1997). The Econometrics of Financial Markets, Prentice-Hall: Englewood Cliffs, NJ.

DeAngelo, H. \& DeAngelo, L. (2006). The Irrelevance of the MM Dividend Irrelevance Theorem. Journal of Financial Economics, 79, 293-315.

Elton, Edwin J., Gruber, Martin J., \& Blake, Christopher R. (1996). Survivorship Bias and Mutual Fund Performance. Review of Financial Studies, 9, 1097-1120.

Fama, E. F. \& French, K. R. (1993). Common risk factors in the returns on stocks and bonds. Journal of Financial Economics 33, 3-56.

Fama, F.E., Lawrence, F., Jensen, Michael C., \& Richard R. (1969). The Adjustment of Stock Prices to New Information. International Economic Review, 10, 1-21.

Geczy, C. C., Stambaugh, R. F., \& Levin, D. (2005). Investing on socially responsible Mutual funds. Working Paper. The Rodney L. White Center of Financial Research, the Wharton School, University of Pennsylvania. Retrieved from: http://papers.ssrn.com/sol3/papers.cfm? abstract_id=416380

Hakim, S. \& Rashidian, M. (2002). Risk \& Return of Islamic Stock Market Indexes. Conference paper presented at Economic Research Forum Annual Meeting Sharjah UAE October 26th. Retrieved from: http://www.lariba.com/knowledgecenter/articles/index.htm.

Hong, H. \& Kacperczyk, M. (2009). The price of sin: The effects of social norms on Markets. Journal of Financial Economics, 93(1), 15-36.

Hussein, Khaled A. (2005). Islamic Investment: evidence from Dow Jones and FTSE Indices. Working paper, Islamic Business Research Centre, Norway.

Lee, D. D. \& Faff, R. W. (2009). Corporate sustainability performance and idiosyncratic risk: A global perspective. The Financial Review, 44(2), 213-237.

Loughran, T. \& Ritter, J. (1995). The New Issues Puzzle. Journal of Finance, 50(1), 23-51.

Marsden, A. (2000). Shareholder Wealth Effects of Rights Issues: Evidence From The New Zealand Capital Market. Pacific-Basin Finance Journal, 8, 419-442.

Michaely, R., Thaler, R. H., \& Womack, K. L. (1995). Price reaction to dividend initiations and Omissions: Overreactions or Drift? The Journal of Finance, 50 (2).

Pett, T., Francis, J., \& Van Ness, R. (2003). Cancellation of Mergers and Acquisitions Implications for Target Firms. Journal of Management Research, 3, 1-10.

Rahim, Ruzita A., \& Yong, O. (2010). Initial returns of Malaysian IPOs and Shariah-compliant status. Journal of Islamic Accounting and Business Research, 1(1), 60-74.

Ray, K. (2011). Market Reaction to Bonus Issues and Stock Splits in India: An Empirical Study. The IUP Journal of Applied Finance, 17, 54-69.

Sadeghi, M. (2008). Financial Performance of Shariah-Compliant Investment: Evidence from Malaysian Stock Market. International Research Journal of Finance and Economics, 20, 15-26.

Subramani, M. \& Walden, E. (2001). The impact of e-commerce announcements on the market value of firms. Information Systems Research, 12 (2), 135-154 